medRxiv preprint doi: https://doi.org/10.1101/2021.08.11.21261897; this version posted August 12, 2021. The copyright holder for this preprint (which was not certified by peer review) is the author/funder, who has granted medRxiv a license to display the preprint in perpetuity. It is made available under a CC-BY-NC 4.0 International license.

\title{
Pleural fluid analysis in neutropenia
}

Isadore M. Budnick, MD¹, Samuel F. Oliver, $\mathrm{MD}^{2}$, Andrew J. Barros, MD², Jeffrey M. Sturek, $\mathrm{MD}, \mathrm{PhD}^{2}$

${ }^{1}$ Department of Medicine, University of Virginia School of Medicine, Charlottesville, Virginia, USA

${ }^{2}$ Division of Pulmonary and Critical Care, Department of Medicine, University of Virginia School of Medicine, Charlottesville, Virginia, USA

Corresponding Author (Name): Jeffrey M. Sturek, MD, PhD

Corresponding Author (Address): UVA Division of Pulmonary and Critical Care, PO Box

800546, Clinical Department Wing 1 Hospital Drive, Charlottesville, VA 22908-0546

Corresponding Author (E-mail): JMS3HK@hscmail.mcc.virginia.edu

Summary conflict of interest statements: The above authors have no conflicts of interest to report.

Funding information: Jeffrey Sturek is supported in part by the National Center For Advancing Translational Sciences of the National Institutes of Health under Award Numbers UL1TR003015 and KL2TR003016.

KEY WORDS LIST

1. Pleural effusion

2. Neutropenia

3. Clinical Decision Making

4. Test characteristics

ABBREVIATIONS LIST

LR - Likelihood ratio 
medRxiv preprint doi: https://doi.org/10.1101/2021.08.11.21261897; this version posted August 12, 2021. The copyright holder for this preprint (which was not certified by peer review) is the author/funder, who has granted medRxiv a license to display the preprint in perpetuity.

It is made available under a CC-BY-NC 4.0 International license.

\begin{abstract}
Light's criteria is the standard for determining the etiology of pleural effusions. Test characteristics of Light's criteria varies in different populations, and Light's criteria may misclassify effusions in patients with impaired immunity such as in neutropenia. This study evaluates the test characteristics of Light's criteria and other clinically available pleural fluid tests in a cohort of patients with neutropenia. Cases were defined as a thoracentesis performed with an absolute neutrophil count of less than 1000 cells/ $\mu$ l documented at least 24 hours prior to the procedure. The etiology of the effusion was adjudicated by independent review of the case data and hospital course by two board certified pulmonologists. Categories for final diagnosis included exudate due to infection, exudate due to malignancy, exudate due to other, and transudate. A total of 83 thoracenteses from 80 patients were identified. Comorbidities included hematologic and solid tumor malignancies, recipients of allogeneic stem cell and solid organ transplants, heart failure, chronic kidney disease, and decompensated cirrhosis. Light's criteria had a sensitivity of $92 \%$ and a specificity of $55 \%$ for identifying exudates, LR+ 2.07 and LR-0.14. A pleural fluid protein value of $>2.9 \mathrm{~g} / \mathrm{dl}$ had a sensitivity of $42 \%$ and a specificity of $96 \%$, LR+11.12 and LR- 0.61. When comparing exudative effusions, the percentage of neutrophils in the pleural fluid was significantly higher in infection, despite peripheral neutropenia. Together these results show a reduced specificity of Light's criteria in neutropenia, and underscore the complexity of pleural effusions in this setting.
\end{abstract}


medRxiv preprint doi: https://doi.org/10.1101/2021.08.11.21261897; this version posted August 12, 2021. The copyright holder for this preprint (which was not certified by peer review) is the author/funder, who has granted medRxiv a license to display the preprint in perpetuity. It is made available under a CC-BY-NC 4.0 International license .

Light's criteria remains the standard for pleural fluid analysis ${ }^{1}$. Light's criteria has superb sensitivity but less robust specificity, particularly in certain populations ${ }^{2}$. Hematopoietic stem cell transplant recipients and patients with hematologic malignancies often develop pleural effusions $^{3,4}$. Cohort studies within these populations have used Light's criteria as the reference standard for case adjudication; however, the majority of effusions were classified as transudate or exudate without a specific etiology $y^{3,4,5,6}$. Light's criteria may misclassify effusions in patients with neutropenia and lead to difficulties with identifying causative etiologies. This study examines the test characteristics of Light's criteria and other pleural fluid tests that help to identify exudative effusions in a cohort of patients with neutropenia.

\section{Methods}

Study was approved by UVA Health-Sciences Research IRB with approval number 22067. This study is retrospective with a waiver of patient consent. This cohort was created by querying the University of Virginia data warehouse for thoracenteses performed between March 2011 and June 2020 on patients who were neutropenic at least 24 hours prior to the thoracentesis. Neutropenia was defined by an absolute neutrophil count of less than 1000 cells $/ \mu \mathrm{l}$. All etiologies of neutropenia and indications for thoracentesis were included in this study. Clinical data, pleural fluid data, serum lab data, and imaging studies were extracted from the electronic medical record and stored in a REDCap database ${ }^{7,8}$.

\section{Case Adjudication}

A summary of the index hospitalization was generated by authors IB and SO. Two board certified pulmonologists (AB and JS) independently reviewed the available data and case summary to determine the etiology of the effusion. After the independent review, the independent outcomes were compared and a consensus outcome was obtained. Categories for final diagnosis included exudate due to infection, exudate due to malignancy, exudate due to other, and transudate. Case definitions were established prior to case adjudication and were based on review of available clinical data as outlined in prior studies ${ }^{9}$.

\section{Data analysis}

Determining if an effusion was an exudate was the outcome of interest. Case adjudication was the reference standard. Sensitivity, specificity, positive likelihood ratio (LR+), and negative likelihood ratio (LR-) were determined for each of the following: Light's criteria, two-test rule, three-test rule, and the individual components of these tests as previously described $^{1,9}$. Analysis of pleural fluid cholesterol was not completed due to the limited number of samples in this cohort.

Pleural fluid data from the exudates due to infection and exudates due to malignancy were compared. The variables of interest included pleural fluid values of $\mathrm{pH}, \mathrm{LDH}$, protein, glucose, total cell count, and cell count differential. Mean values and standard deviations were calculated for these variables. An independent sample t-test assuming unequal variances was used for comparison of mean values. Two-tail $p$ values were reported with each variable of interest. A Bonferroni correction was performed to correct for multiplicity with a familywise error rate of 0.05 . 
medRxiv preprint doi: https://doi.org/10.1101/2021.08.11.21261897; this version posted August 12, 2021. The copyright holder for this preprint (which was not certified by peer review) is the author/funder, who has granted medRxiv a license to display the preprint in perpetuity. It is made available under a CC-BY-NC 4.0 International license .

\section{Results}

\section{Baseline demographics}

The search query identified 83 thoracenteses from 80 patients. The median age was 61.6 years old and $48.8 \%$ were male. The cohort was comprised of individuals with hematologic and solid tumor malignancies, including acute or chronic leukemia (26.3\%), lymphoma of unspecified subtype (18.8\%), non-pulmonary solid tumors $(21.3 \%)$, and pulmonary solid tumors (13.8\%). The cohort also included recipients of allogeneic stem cell transplants $(11.3 \%)$, recipients of solid organ transplants (11.3\%), individuals with heart failure (12.0\%), chronic kidney disease $(7.2 \%)$, and decompensated cirrhosis (8.4\%). Duration of neutropenia prior to thoracentesis varied within the cohort. $30.1 \%$ of thoracenteses occurred with neutropenia of less than 48 hours, $15.7 \%$ with neutropenia of less than 7 but greater than 2 days, $28.9 \%$ with neutropenia of less than 30 but greater than 7 days, and $25.3 \%$ with neutropenia of greater than 30 days. The pleural effusions were determined by case adjudication to be transudates in $33.7 \%$ cases, exudates due to infection in $37.3 \%$, exudates due to malignancy in $25.3 \%$, and exudates due to other etiology in $3.6 \%$.

\section{Test characteristics}

Light's criteria had a sensitivity of $92 \%$ and specificity of $55 \%$ for determining if the effusion was an exudate with an associated LR+ 2.07 and LR- 0.14 (Table). Pleural fluid/serum protein ratio $>0.5$ had a sensitivity of $58 \%$ and specificity of $89 \%$ with an associated LR+ 5.22 and LR- 0.47 (Table). Pleural fluid protein values $>2.9 \mathrm{~g} / \mathrm{dl}$ had a sensitivity of $42 \%$ and a specificity of $96 \%$ with a corresponding LR+ 11.12 and LR- 0.61 (Table). All other tests had inferior test characteristics (Table).

\section{Exudative effusions}

Pleural fluid studies from the exudates due to infection versus exudates due to malignancy were compared to determine significant differences. Percentage of neutrophils within the pleural fluid cell count was significantly higher in the exudate due to infection as compared to exudate due to malignancy (Figure). None of the other variables of interest had a statistically significant difference between groups (Figure).

\section{Discussion}

This study is the first to analyze the test characteristics of Light's criteria in a cohort of neutropenic patients using the clinical diagnosis as the reference standard. Light's criteria demonstrated similar sensitivity but worse specificity compared to prior studies ${ }^{2,10}$. Light's criteria specificity could suffer due to nonspecific protein and LDH elevations in inflammatory chronic conditions wherein neutropenia is common ${ }^{10}$. Pleural fluid protein $>2.9 \mathrm{~g} / \mathrm{dl}$ and pleural fluid/serum protein $>0.5$ had robust LR+ in this population, which is similar to other studies ${ }^{7}$. Pleural fluid neutrophil percentage distinguished exudate due to infection versus malignancy despite the presence of neutropenia. Strengths of this study include independent case adjudication and clinical diagnosis as case definition. Limitations include cohort size and variable etiologies and duration of neutropenia. Future studies could utilize a similar approach but focus on a particular etiology of neutropenia. 
medRxiv preprint doi: https://doi.org/10.1101/2021.08.11.21261897; this version posted August 12, 2021. The copyright holder for this preprint (which was not certified by peer review) is the author/funder, who has granted medRxiv a license to display the preprint in perpetuity.

It is made available under a CC-BY-NC 4.0 International license .

\section{References}

1. Light RW, Macgregor MI, Luchsinger PC, Ball WC Jr. Pleural effusions: the diagnostic separation of transudates and exudates. Ann Intern Med. 1972;77(4):507-513.

2. Porcel JM. Identifying transudates misclassified by Light's criteria. Curr Opin Pulm Med. 2013;19(4):362-367.

3. Modi $\mathrm{D}$, Jang $\mathrm{H}$, Kim S, et al. Incidence, etiology, and outcome of pleural effusions in allogeneic hematopoietic stem cell transplantation. Am J Hematol. 2016;91(9):E341E347.

4. Adam AK, Zamlut M, Soubani AO. The yield and safety of thoracentesis in hematopoietic stem cell transplantation recipients. Lung. 2007;185(5):257-262.

5. Faiz SA, Bashoura L, Lei X, et al. Pleural effusions in patients with acute leukemia and myelodysplastic syndrome. Leuk Lymphoma. 2013;54(2):329-335.

6. Bass J, White DA. Thoracentesis in patients with hematologic malignancy: yield and safety. Chest. 2005;127(6):2101-2105.

7. PA Harris, R Taylor, R Thielke, J Payne, N Gonzalez, JG. Conde, Research electronic data capture (REDCap) - A metadata-driven methodology and workflow process for providing translational research informatics support. J Biomed Inform. 2009 Apr;42(2):377-81.

8. PA Harris, R Taylor, BL Minor, V Elliott, M Fernandez, L O'Neal, L McLeod, G Delacqua, F Delacqua, J Kirby, SN Duda, REDCap Consortium, The REDCap consortium: Building an international community of software partners. J Biomed Inform. 2019 May 9.

9. Wilcox ME, Chong CA, Stanbrook MB, Tricco AC, Wong C, Straus SE. Does this patient have an exudative pleural effusion? The Rational Clinical Examination systematic review. JAMA. 2014;311(23):2422-2431.

10. Chubb SP, Williams RA. Biochemical Analysis of Pleural Fluid and Ascites. Clin Biochem Rev. 2018;39(2):39-50. 


\begin{tabular}{|c|c|c|c|c|c|}
\hline Parameter & $\begin{array}{l}\text { Sample } \\
\text { size, n }\end{array}$ & $\begin{array}{l}\text { Sensitivity, } \\
\%\end{array}$ & Specificity, \% & $\mathrm{LR}+$ & LR- \\
\hline Light's criteria & 78 & 92 & 55 & 2.07 & 0.14 \\
\hline $\begin{array}{l}\text { Pleural fluid } \\
\text { protein/serum } \\
\text { ratio }>0.5\end{array}$ & 77 & 58 & 89 & 5.22 & 0.47 \\
\hline $\begin{array}{l}\text { Pleural fluid } \\
\mathrm{LDH} / \text { serum } \\
\mathrm{LDH} \text { ratio > } \\
0.6\end{array}$ & 67 & 68 & 59 & 1.67 & 0.54 \\
\hline $\begin{array}{l}\text { Pleural fluid } \\
\mathrm{LDH}>2 / 3 \text { ULN }\end{array}$ & 76 & 60 & 73 & 2.23 & 0.55 \\
\hline Two-test rule & 77 & 84 & 38 & 1.37 & 0.41 \\
\hline $\begin{array}{l}\text { Three-test } \\
\text { rule }\end{array}$ & 77 & 90 & 40 & 1.51 & 0.24 \\
\hline $\begin{array}{l}\text { PF Protein > } \\
2.9\end{array}$ & 78 & 42 & 96 & 11.12 & 0.61 \\
\hline $\begin{array}{l}\text { PF LDH > } \\
0.45 \text { ULN }\end{array}$ & 76 & 83 & 42 & 1.42 & 0.42 \\
\hline
\end{tabular}

Table. Neutropenic Pleural Fluid Test Characteristics 


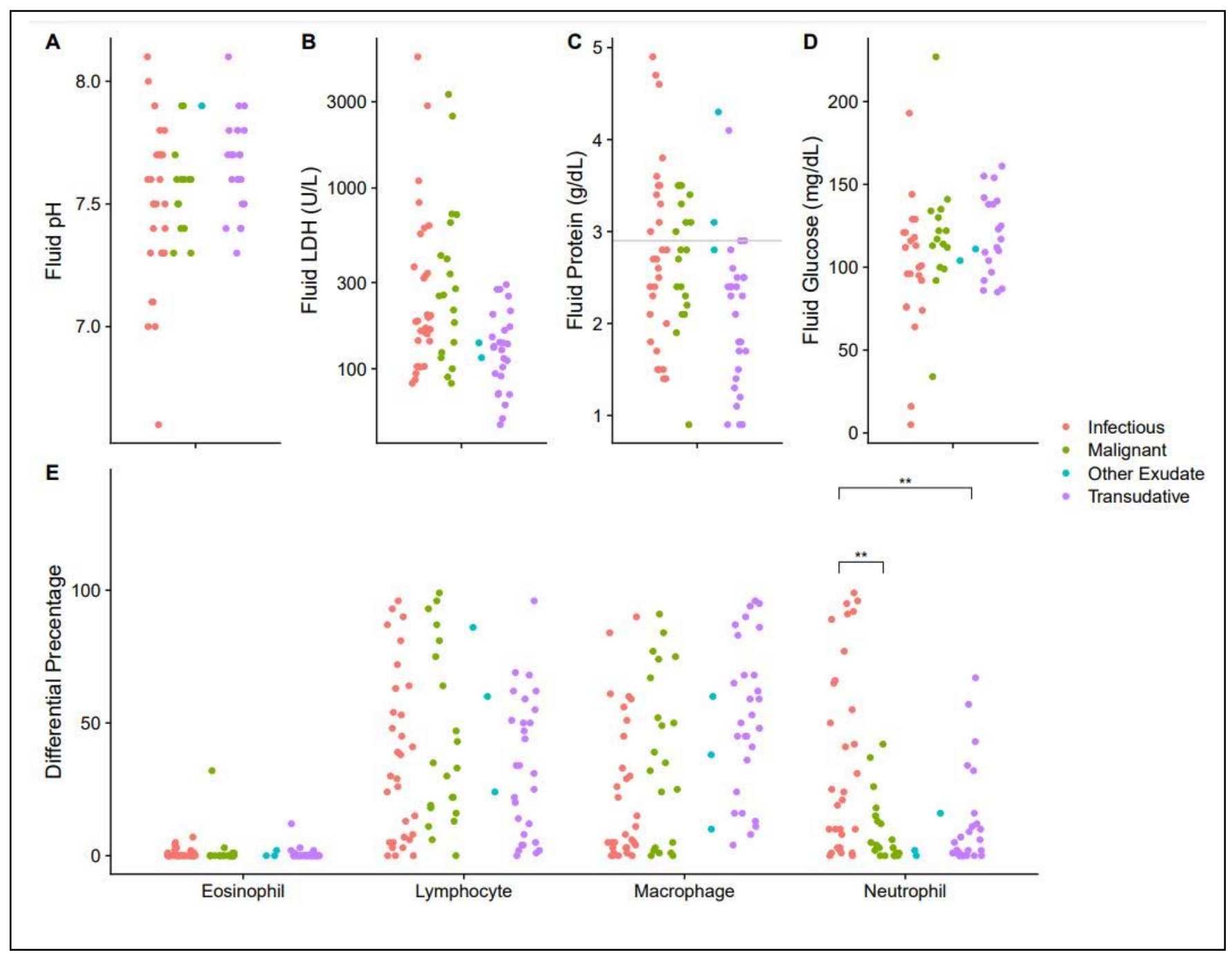

Figure. Neutropenic Pleural Fluid Laboratory Results. A-D, Comparison of fluid pH, LDH, protein, and glucose, respectively, between all four case categories. Horizontal line in $\mathrm{C}$ represents pleural fluid protein 2.9 as referenced in Table. E, Comparison of fluid cell profile between all four case categories. ${ }^{* *} P$ value determined by Bonferroni correction with familywise error rate of 0.05 . 